\title{
Climate adaptation at what scale? Multi-level governance, resilience, and coproduction in Saint Louis, Senegal
}

\author{
Trond Vedeld ${ }^{1}$ (iD $\cdot$ Adrien Coly ${ }^{1}$. \\ Ndèye Marème Ndour ${ }^{1} \cdot$ Siri Hellevik ${ }^{1}$
}

Received: 27 January 2015/Accepted: 12 June 2015/Published online: 7 July 2015

(C) The Author(s) 2015. This article is published with open access at Springerlink.com

\begin{abstract}
This paper utilizes a multi-level governance framework to explain how and at what scale climate adaptation, exemplified by flood risk management, was governed in the medium-scale city of Saint Louis, Senegal. It explores how this policy sector worked toward a "resilient city" pointing to gaps between governance as prescribed and as practiced. The paper suggests that strong coordination of climate change adaptation and flood risk management should take place at city level, reflecting the "place-based" character of these policy sectors. However, adaptation cannot be addressed successfully at any single geographic scale or by any one category of actor. Effective collaboration across politico-administrative boundaries at multiple scales is required in order to address tensions between competing policy agendas and tackle socio-spatial inequality and vulnerability. We found that public officials at the city and regional state level encouraged some degree of citizen participation in planning and input into adaptation. However, despite emerging networks for city-level coordination and capacity to adapt to flood risks among local residents, there were limitations in how higher-level government and institutions supported the lower levels in vertical and horizontal coordination. In particular, services and investments within poor and vulnerable settlements were lacking. This undermined the capability of municipal staff for local engagement and for diverse groups of residents to become really effective partners with the government in coproducing services required to enhance resilience. More so, it limited opportunities to bring local actions to scalebeyond the city boundaries and toward transitional adaptation and transformation.
\end{abstract}

Keywords Climate resilience in urban Africa · Adaptation · Transformation · Multi-level governance $\cdot$ Floods $\cdot$ Coproduction

Trond Vedeld

trond.vedeld@nibr.no

1 Norwegian Institute for Urban and Regional Research (NIBR), Oslo, Norway 


\section{Introduction}

Climate change and extreme weather represent significant challenges to cities in Africa. A variety of actors are involved in urban climate governance at multiple levels; many observers pointing to the city as a critical strategic arena for coordinating actors and sectors, and enhancing resilience (Betsill and Bulkeley 2007; Pelling 2011; Bulkeley 2013). However, in many African cities, the urban authorities have often not been capable or willing to provide the coordination and leadership required to further local climate governance, reflecting tensions between competing policy agendas, e.g., between development (for the poor) and environmental agendas. Often the municipal level has not been provided powers and financial resources from the national state level to ensure appropriate adaptation capacity. There are exceptions to this, obviously, and many cities in Africa (and across the world) are increasingly taking a high degree of leadership in preparing adaptation programmes and protection against extreme weather and related disasters. This may happen even in the absence of specific guidance and support from national policies and enabling institutional frameworks (Simon 2010; Cartwright et al. 2012; Roberts and O’Donoghue 2013; UN-HABITAT 2014; Pauleit et al. 2015; Wisner et al. 2015).

We ask, at what scale is climate adaptation governed and what role does the city and sub-city levels play in a medium-scale coastal African city? To what extent has the perceived need to adapt led to substantive changes in adaptive action, policies, institutions, policy instruments, and governance? What drivers and barriers do the city government and residents face in adapting to climate change and building resilience?

It is largely accepted that city governments need to bring coherence to agendas that have previously been addressed in uncoordinated manners, e.g., climate change adaptation, disaster risk management, and sustainable development (Satterthwaite et al. 2007, 2009; Birkmann and von Teichmann 2010; Satterthwaite 2011; Pelling 2011; Bulkeley 2010, 2013; O'Brien 2012). Reflecting the significance of the city as an appropriate scale for climate governance, the concept of resilient cities has been widely promoted as a desirable goal within the policy context of climate change (UN-HABITAT 2011; UNISDR 2012, 2014; ICLEI 2014; Satterthwaite and Dodman 2013). However, it is also widely recognized that many cities in both developing countries and developed countries are confronted by important barriers to the institutionalization of the climate risk agenda. Municipal authorities' capacity to act on adaptation is often severely constrained by how the state operates within multi-level governance to restrict mandates and resources at city, sub-city, and local/community levels. Moreover, urban authorities need to tackle tensions in political priorities between short-term development needs and long-term climate risk reduction (Satterthwaite 2011; Leck and Simon 2013; Satterthwaite and Dodman 2013; Vedeld et al. 2012, 2015a, b).

Saint Louis is to this end a "typical" medium-scale coastal city in Africa faced with a diversity of climate risks (heat, droughts, cloudbursts, and diverse types of floods) (Diagne 2007; Coly et al. 2012, CLUVA 2014a, b). Medium-scale cities represent the most important kinds of cities within which the majority of the urban African population live, and thus, it is important to learn more about how climate adaptation is governed in such cities. This paper contributes to an understanding of how adaptation is established and practiced through coproduction in multi-level governance in a typical medium-scale coastal African city operating under extreme financial constraints and relatively centralized hierarchical steering. 
The study was designed as an analysis of how urban flood risk management and attention to extreme weather events is integrated in multi-level governance-as it interfaces with the climate change adaptation agenda at city and sub-city levels. Flood risks were considered as local manifestations of (extreme) climate risks and extreme weather, e.g., heavy rainfall and floods/flash floods (Douglas et al. 2009). The focus on the local level was motivated by the fact that climate change will impact locally and differently across urban neighborhoods and social groups. By studying adaptation experiments in their local context, we were better able to consider whether they addressed local needs and demands and opened up for transitions in governance or transformative pathways.

The amount of research undertaken on urban vulnerability and climate change adaptation in developing countries has increased considerably over the last few years (Adger et al. 2009; Ziervogel and Parnell 2012; Carmin et al. 2012; Satterthwaite and Dodman 2013; Roberts and O'Donoghue 2013; Inderberg et al. 2015). An increasing number of such urban adaptation studies have also addressed governance challenges toward establishing resilient cities. This reflects that critical obstacles to effective adaptation are precisely perceived to lie in the governance structure or in politico-institutional factors (Betsill and Bulkeley 2007; OECD 2009; Bicknell et al. 2009; Kern and Alber 2009; Pelling 2011; Cartwright et al. 2012; Herslund et al. 2012; Vedeld et al. 2012; 2015b; Satterthwaite and Dodman 2013; Bulkeley 2013; Hanssen et al. 2013). This study aims to contribute to this debate.

An increasing volume of adaptation research and studies is also coming out of Africa. Diagne investigated governance and flood risks issues in Saint Louis in 2007 (Diagne 2007). Simon (2010) provided an early Africa-wide survey of climate change challenges. Beyond the UN-HABITAT Global Report from 2011 (UN-HABITAT 2011), there is the more recent State of African Cities reports that cover climate issues (UN-HABITAT 2014) as well as work by the World Bank/GFDRR (e.g., World Bank 2012). The rich literature on adaptation in South Africa also includes work governance and city level issues, e.g., from studies of Cape Town and Durban (Ziervogel and Parnell 2012; Cartwright et al. 2012; Roberts and O'Donoghue 2013; Ziervogel et al. 2014).

Much of the urban climate work on Africa is, however, on large cities, including most of the work under the CLUVA project (CLUVA 2014a, b, Pauleit et al. 2015). ${ }^{1}$ To this extent, Wisner et al. (2015) represent a counterpoint to this research and deal with how small African cities and towns confront climate change. The city scale in promoting adaptation is also a topic in Vedeld et al. (2015b), who compared constraints on climate governance in a medium-scale town (Saint Louis) to those on a large city (Dar es Salaam). Some observers in this regard suggest that larger city municipalities will have greater capacity and resources, and thus an advantage in integrating adaptation in governance and effectively building a resilient city compared to smaller ones (Rauken et al. 2014). Analyzing approaches to adaptation within Saint Louis from a perspective of multi-level governance, we put forward a different hypothesis, however. We argue that it is not the size and scale of the municipality which is decisive for the functioning of local climate risk management. Rather, it is the way the arrangement of coproduction operates within the system of multilevel governance, and how public officials relate to key stakeholders and residents that best explains the modes of adaption approaches and achievements.

\footnotetext{
${ }^{1}$ Within the EU-funded Climate Change and Vulnerability in Africa (CLUVA), the following five cities were researched: Addis Ababa, Dar es Salaam, Douala, Ouagadougou, and Saint Louis (CLUVA 2014a, b; Pauleit et al. 2015; Vedeld et al. 2015a, b).
} 


\section{Analytical framework}

The integration of adaptation into government (and governance) across levels and scales is considered critical to long-term climate resilience (Bulkeley 2013). The focus on resilience and resilient cities is of relevance to all urban settings and concerns "capacities to withstand or recover from all direct and indirect impacts of climate change" (Pelling 2011; Satterthwaite and Dodman 2013:292; UNISDR 2014). Resilience can be defined more precisely as:

The ability of a system and its component parts to anticipate, absorb, accommodate, or recover from the effects of a hazardous event in a timely and efficient manner, including through ensuring the preservation, restoration, or improvement of its essential basic structures and functions (IPCC 2012:3).

The resilience discourse within the climate adaptation literature is allied with contemporary governance discourses about the sharing of responsibilities between state and non-state actors for climate risk management at different scales, and conditions for innovation and change toward a new, more sustainable system state. This inherently normative stand relates to discussions about transitional adaptation and transformation (Pelling 2011). The framework of analysis makes use of three "levels of adaptation" (inspired by Pelling 2011; Bulkeley 2013). The least far-reaching type is incremental adaptation (often of no-regrets type) that does not question the fundamentals of the socioecological and politico-institutional system of concern. Incremental adaptation measures mirror resilience more narrowly defined (Pelling 2011). Transition or transitional adaptation mainly refers to more significant adjustments within governance and institutional

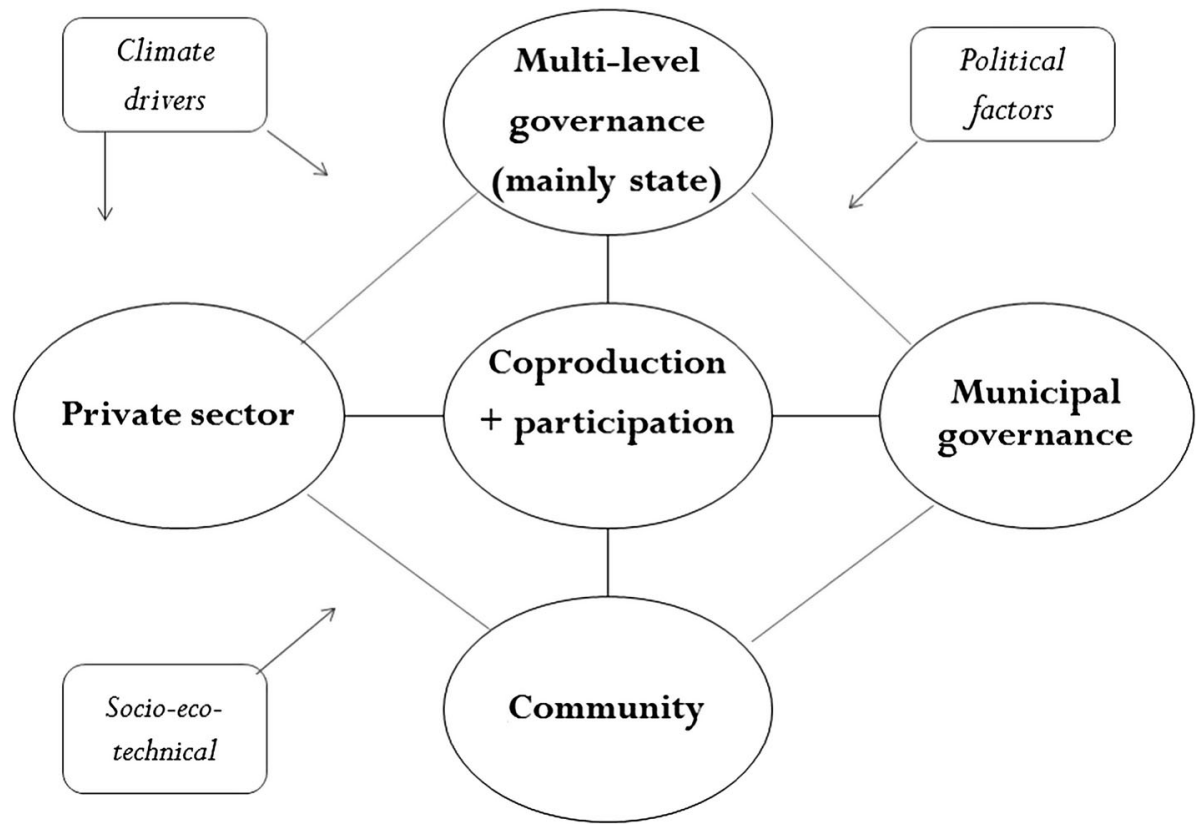

Fig. 1 Multi-level governance and coproduction (Authors' own design; inspired by Ostrom 1996; Bulkeley 2013) 
arrangements to make full use of their potentials. The most wide-reaching level of adaptation can be referred to as transformation. Transformation addresses the root causes of climate change and ways of managing climate risks and presupposes profound changes in the political and economic system (Pelling 2011; Bulkeley 2013; Inderberg et al. 2015).

In the analysis, we bring together theories from (i) multi-level governance, (ii) coproduction (and related network governance theory), and (iii) resilient cities. The governance analysis explains the interplay between actors, levels, and sectors of government in addressing complex public policy challenges related to climate risk management - as a wicked problem (Bache and Flinders 2004; Betsill and Bulkeley 2007; Weber and Khademian 2008; Peters 2008; Sorensen and Torfing 2009; Osborne 2010; Bulkeley 2013; Sorensen and Torfing 2014). Coproduction is defined as "the process through which inputs used to produce a good or service are contributed by individuals who are not 'in' the same organisation" (Ostrom 1996: 86). The focus of the analysis was particularly on how coordination and cooperation were enabled at two local levels: (i) municipal level (city and sub-city levels) and (ii) local community level. The analysis of coproduction within multilevel governance focused on the encounters at the interface between public officials and diverse citizen groups (and private sector) related to forms of collaboration (engagement/ disengagement) and forms and degrees of participation in service delivery and possible coproduction in flood risk management (Ostrom 1996, 2005, Bulkeley 2013).

Figure 1 suggests the institutional focus of the analysis. Multi-level governance, which is typically state and hierarchy dominated, places constraints on the powers and capacity for municipal governance (through processes of decentralization/devolution, deconcentration of state bodies/capacity to regional/city levels and delegation of powers to community actors or to a variety of (semi-) autonomous corporations or private agencies (e.g., in water supply or sewerage provisioning) (Vedeld 2003; Betsill and Bulkeley 2007; Peters 2008; Manor 2011).

\section{Methodology}

The research focus led to a case study approach with a mix of research methods: policy and planning reviews, governance/institutional analysis, in-depth interviews (planners, officials), focus group interviews with citizens, local observations of floods/transect walks, and validation workshops, and meetings with local officials, civil society, and academia. Altogether, we conducted 30 semistructured interviews in the city with different types of actors (public, private, civic) and at different levels, allowing for a variety of topics and perspectives to be addressed. Each interview lasted close to $2 \mathrm{~h}$ and was conducted mostly in the office of the interviewee by a lead interviewer and 2-3 team members. Background research involved an institutional survey and socioeconomic surveys, including mapping of civil society organizations and assessment of local/community capacity in each of the case study areas (Coly et al. 2011b, c; Coly et al. 2012).

We first explored which institutions and policy sectors were involved and relevant for "climate adaptation and flood risk management at city and community levels" which was our main research "case." Urban authorities were perceived confronted by the "triple" governance challenge of (i) planning new settlements for a rapidly increasing population; (ii) meeting existing gaps in providing quality service delivery and infrastructure for all citizens and addressing underlying (climate) vulnerabilities, including for the poorest and most risk exposed; and (iii) addressing "new" or future climate risks such as floods. 
Consequently, the empirical data collection focused on the integration of climate risks/ adaptation in three key sectors and related actors/agencies considered critical for addressing climate adaptation governance: (i) urban planning (strategic, land use, and development planning); (ii) water resources management (flood risk and storm water management, sewerage, water supply); and (iii) disaster risk management. A wide range of complementary adaptation and disaster risk management approaches are available to enhance resilience from reducing risks and exposure and vulnerability to responding to and recovering from flood emergencies (IPCC 2012, 2014). In concrete terms, we looked for actions considered critical to promote resilience at the level of the local communities (ref. key criteria identified in the Ten Essentials for Making Cities Resilient, UNISDR 2012, 2014), including, inter alia: whether or not climate action plans had been established (and through participatory approaches); existence of institutional homes and mandates for understanding and addressing key issues; functioning coordination mechanisms for risk reduction; assigned staff, budgets, and resources; risk and vulnerability assessments carried out; early warning systems and emergency management capacities existing; planning and zoning principles that were enforced and respected; critical services and infrastructure in place, e.g., for storm water and dykes; and whether broader underlying vulnerabilities were addressed in ways responsive to local residents.

We carried out in-depth fieldwork in two case study areas: Diaminar (on Sor Island) and Goxxumbacc (on Lange de barbarie) (see Fig. 4).

\section{Drivers and barriers}

The multi-level governance framework was utilized to systematically analyze and understand the integration of climate adaptation policies and flood risk management across sectors, actors, and levels (Fig. 1) (Osborne 2010; Pelling 2011; Bulkeley 2013). The extent to which different modes of governance were actually deployed at different levels and were successful was considered the result of different factors that acted as both drivers and barriers to the cooperation or coproduction of knowledge and action between state, municipal, and non-state actors. Many actors were involved in climate and flood risk governance at different levels and scales-well above 20 public/semipublic agenciesmost of them anchored with the regional state authorities, not with the municipality. In fact, the combined investments within the city territory of these state agencies were much larger than those of the municipality. The regional and local institutional richness reflected upon the institutional history of Saint Louis as a former capital of the French West Africa and an important administrative, educational, and economic city in Senegal. We distinguished three sets of factors: institutional, political, and sociotechnical (including ecological) (Bulkeley 2013), in addition to climate drivers (cf. Fig. 1).

Institutional factors in our study are those that shape the capacity of urban institutions at all levels - both formal and informal - to respond to hazards and withstand or improve systems' resilience. Our key focus was on institutional factors related to the multi-level governance context within which urban adaptive capacity was enabled and capacity to act and respond to climate risks at local levels largely determined. The institutional factors were conditioned by political factors, sociotechnical factors, and climate drivers. From an adaptation perspective, we needed to understand who and what needed to become more resilient, i.e., individual citizens and their assets in local settlements that were exposed and vulnerable to floods. They needed support from resilient services and governance systems. 
Regarding the state level and state-municipal interactions within the broader institutional arrangements, we investigated how the state, at national and regional levels, worked through different governance modes in vertical and horizontal coordination in the selected sectors to balance powers and resources. We were interested in how the state made available (or not) the powers, mandates, and financial and other resources for the municipality as well as how various state agencies operated on the ground within the city boundaries. At the municipal level, we analyzed organizational arrangements and operations of the municipality in relation to different ideal modes of municipal governance (specific set of processes and techniques that municipal authorities deployed, related resources and knowledge). Bulkeley distinguishes at least six modes of municipal-led governance: municipal self-governing, provisioning (by the municipality itself of services and infrastructure), municipal regulation (through hierarchical steering and control), enabling, non-state voluntary, and public-private provisioning (for detailed explanation cf. Ostrom 1996, Kern and Alber 2009; Bulkeley 2013; Sorensen and Torfing 2014). These different modes can be more or less hierarchical, market-, or network-oriented. At community, neighborhood, or sub-city levels, civil society actors or private business would interact and condition municipal actions from above and from below, or engage in nonstate voluntary or community self-regulation modes of governance (de Sardan 2011).

Political factors were also considered important, although less central to our analysis (due to limitations of data). Political factors here related to the attention to adaptation (risks and vulnerabilities) given by the political leadership at different levels (e.g., district level officials, municipal councillors, the Mayor) within the political-economic context as well as the role of specific economic and political interests and actors who shaped resilience and urban development locally (Bulkeley 2013:102).

Socio-ecological and sociotechnical factors related to the ecosystem context, social and demographic conditions (e.g., socio-spatial inequality), including urbanization trends and forms and settlement patterns (e.g., in flood-exposed areas), and urban landscapes and morphologies (Ostrom 2005; Bulkeley 2013; see other articles in this volume).

\section{Criteria for choice of the city and the local case studies}

Saint Louis was selected as a medium-scale African coastal city highly exposed to diverse types of climate and flood risks (Coly et al. 2012). It was chosen as one of the coastal cities among the five cities studied under CLUVA (CLUVA 2014a, b; Pauleit et al. 2015). It was from the outset considered a relatively good practice case compared to many other African cities on different grounds (see other articles in this journal issues). Saint Louis is a former capital city and regional economic center with the presence of most of the sector agencies relevant for addressing flood risks. As such, the city represents an institutionally "rich" case study. It is conditioned by governance challenges fairly typical of many African cities.

Two local areas selected for in-depth analysis were Diaminar and Goxxumbacc, both selected as particularly flood risk exposed and vulnerable communities. They had a known history of engagement in flood risk management at the level of the community and the district (sub-wards). Diaminar settlement is an informal and mostly unplanned settlement (sub-district of the city) situated on a low-lying area (located on the island of Sor) that is exposed to annual river and flash floods due to inadequate drainage and limited sewerage and storm drain systems. The local houses and buildings are also affected by salinization from seawater intrusion. The second case, Goxxumbacc, is a larger, mostly informal settlement located on the spit Lange de barbarie on the seashore of the Atlantic Ocean. The 
area is mostly exposed to coastal flooding, while flash floods also constitute a problem, but not as severe as in Diaminar. Both areas are subject to various impacts from the floods of the Senegal River (but to lesser degree after the 2003 opening of a new outlet for the River, see below).

The following factors were considered especially important drivers and barriers to climate governance. First, we assumed that the vertical relationships of government and governance were critical for the framing of relationships between state, municipal, and local actors, e.g., determining the responsibilities and powers of the municipality in different sectors, and enabling or constraining coproduction between different government, civic, and private actors (UN-HABITAT 2011; Bulkeley 2013).

Second, experiences of extreme floods in the recent past and increased awareness of risks and vulnerabilities were considered an important possible driver for explaining urban municipal response and various responses at local/community levels. The city has recently experienced several severe flash floods/storm surges and related extreme weather events.

Third, we also considered the degree to which political factors appeared to influence the framing of climate policies at city level and thus approaches to adaptation among planners and other local actors.

Finally, the choice of a medium-scale city and municipality for our inquiry (in contrast to the other larger CLUVA cities) allowed us to test whether size and scale of a city and the capacity of the municipality to adapt seemed to be an important factor for the choice of adaptation approaches and potential success. An argument found in the (Scandinavian) literature on climate change is that a large municipality will typically have more resources and capacity for specialization and allocation of resources to a new policy domain such as adaptation (Rauken et al. 2014).

Salient features about the size, scale, socioeconomic vulnerability, and climate exposure of the city are provided in Table 1.

\section{Findings}

The presentation of the findings from the research is organized as follows. First, we present a brief background to the city of Saint Louis. Second, we reflect upon the vertical statemunicipal relationships. Third, we present the municipal organizational structure and discuss the municipality's capacity to operate within key sectors of concern. Fourth, we analyze the interactional relationships between public officials (state and municipal) and local residents/community-level actors and institutions in relation to coproduction. Fifth, we outline the degree to which different levels of adaptation have been deployed by actors at different scales. Finally, we discuss findings and draw implications for further research and policy.

\subsection{Background to Saint Louis}

The city of Saint Louis is a former capital city (until 1958) and a regional economic center in Northern Senegal (Table 1). It is located on four low-lying islands near the mouth of the Senegal River on the shore of the Atlantic Ocean (Fig. 4). CLUVA's analysis of extreme rainfall events, based on climate projection data until 2050, suggests that intensity and frequency of extreme events will significantly increase and enhance flood risks in the future (Kane 2010; Coly et al. 2011a; Coly et al. 2012; CLUVA 2014b). The city has 
Table 1 Size, vulnerability, and climate drivers in the case study cities (CLUVA 2014b)

\begin{tabular}{|c|c|c|}
\hline & $\begin{array}{l}\text { City-level } \\
\text { indicators }\end{array}$ & $\begin{array}{l}\text { Comments and comparison with typical sub- } \\
\text { Saharan African standard }\end{array}$ \\
\hline \multicolumn{3}{|l|}{ Demography and area } \\
\hline Population size (2012) & 200,000 & $\begin{array}{l}\text { Medium-scale/second-order city (fifth largest in } \\
\text { Senegal) }\end{array}$ \\
\hline Population density & 5000 per $\mathrm{km}^{2}$ & Relatively high density by African standards \\
\hline Size of urban territory & $40 \mathrm{~km}^{2}$ & Small and constrained territory (island location) \\
\hline Rate of population growth & $2.4 \%$ & $\begin{array}{l}\text { Not very high rate by African standards, but } \\
\text { provides challenges to urban planning }\end{array}$ \\
\hline Share of population in informal areas & $29 \%$ & $\begin{array}{l}\text { "Informal areas" are here referred to as } \\
\text { unplanned and underserviced }\end{array}$ \\
\hline Access to piped water & $97 \%$ & Indicates high access rate by African standards \\
\hline Access to sewerage & $15 \%$ & Above average by African standards \\
\hline Reliance on pit latrines & $90 \%$ & Typical/slightly better than African standards \\
\hline $\begin{array}{l}\text { Exposure of people, places, assets- } \\
\text { percentage of territory flood } \\
\text { exposed }\end{array}$ & $\begin{array}{l}\text { All territory flat } \\
\text { and low-lying }\end{array}$ & $\begin{array}{l}\text { All of city territory below } 4 \mathrm{~m} \text { above sea level. } \\
\text { Citywide exposure to river and coastal } \\
\text { flooding, but also to flash floods }\end{array}$ \\
\hline Annual rainfall & $300 \mathrm{~mm}$ & $\begin{array}{l}\text { Heavy cloudbursts common and rainfall } \\
\text { concentrated to short rainy season/intense } \\
\text { rainfall days in period mid-July to mid- } \\
\text { October }\end{array}$ \\
\hline Main flood risk types & $\begin{array}{l}\text { Flash floods, } \\
\text { coastal }\end{array}$ & $\begin{array}{l}\text { Flood risk from Senegal River lowered due to } \\
\text { new channel made in } 2003\end{array}$ \\
\hline Climate/food risk projections & $\begin{array}{l}\text { More extremes } \\
\text { expected }\end{array}$ & $\begin{array}{l}\text { Flood risks to increase due to changes in social } \\
\text { conditions and more intense rainfall events }\end{array}$ \\
\hline
\end{tabular}

experienced several recent extreme flood events from the Senegal River, for example in 1994, 1999, 2000, and 2003. In 2003, the city was under threat of a major flood, which was addressed by spontaneously making a new channel and opening for Senegal River across the spit of Lange de Barbarie (see below). In 2009, a tidal wave impacted, e.g., Goxxumbacc. Drought events have also been serious and recurrent (nine events between 1974 and 2010) (Coly et al. 2012). Severe floods in 2010 and 2012 were mainly due to heavy rains, flash floods, and inadequate drainage systems, reflecting that rainfall has typically fell in heavy cloudbursts between July and October (affecting Diaminar severely) (Vedeld et al. 2012, 2015b; Coly et al. 2012). In 2010, more than 80,000 people or $40 \%$ of the citizens were affected by floods.

It is on the background of such perceived significant climate change risks and experiences of frequent floods (and droughts), combined with increasing population and settlement of people in flood-exposed areas, that the urban authorities from the mid-1990s started to take climate and flood risks more seriously. From around 2005, the city has responded relatively systematically to the climate change adaptation agenda (Diagne 2007; Niang 2007; Coly et al. 2012; Vedeld et al. 2015b).

\subsection{Multi-level governance structure-centralized and hierarchical government}

While the municipality has some degree of autonomy in governance and operations, in reality this autonomy was lacking because the city has very limited powers and legal 
mandates, finances, staff, and technical competence. This undermined the municipal capacity for autonomous self-governing and provisioning of key public services and infrastructure to perform planning and service functions, including the climate risk management. Senegal has basically a three-tier government structure characterized by a relatively strong unitary state, a relatively autonomous, yet weak, municipal level, and an even weaker regional elected level (with elected regional councils). Saint Louis is located within the region of Saint Louis, the regional headquarters being located to the city itself. Key state ministries and agencies appeared fairly top-down and interventionist, at times ambivalent, in their dealing with the municipality and local citizens related to urban planning and development functions. This concerned ministries dealing with important

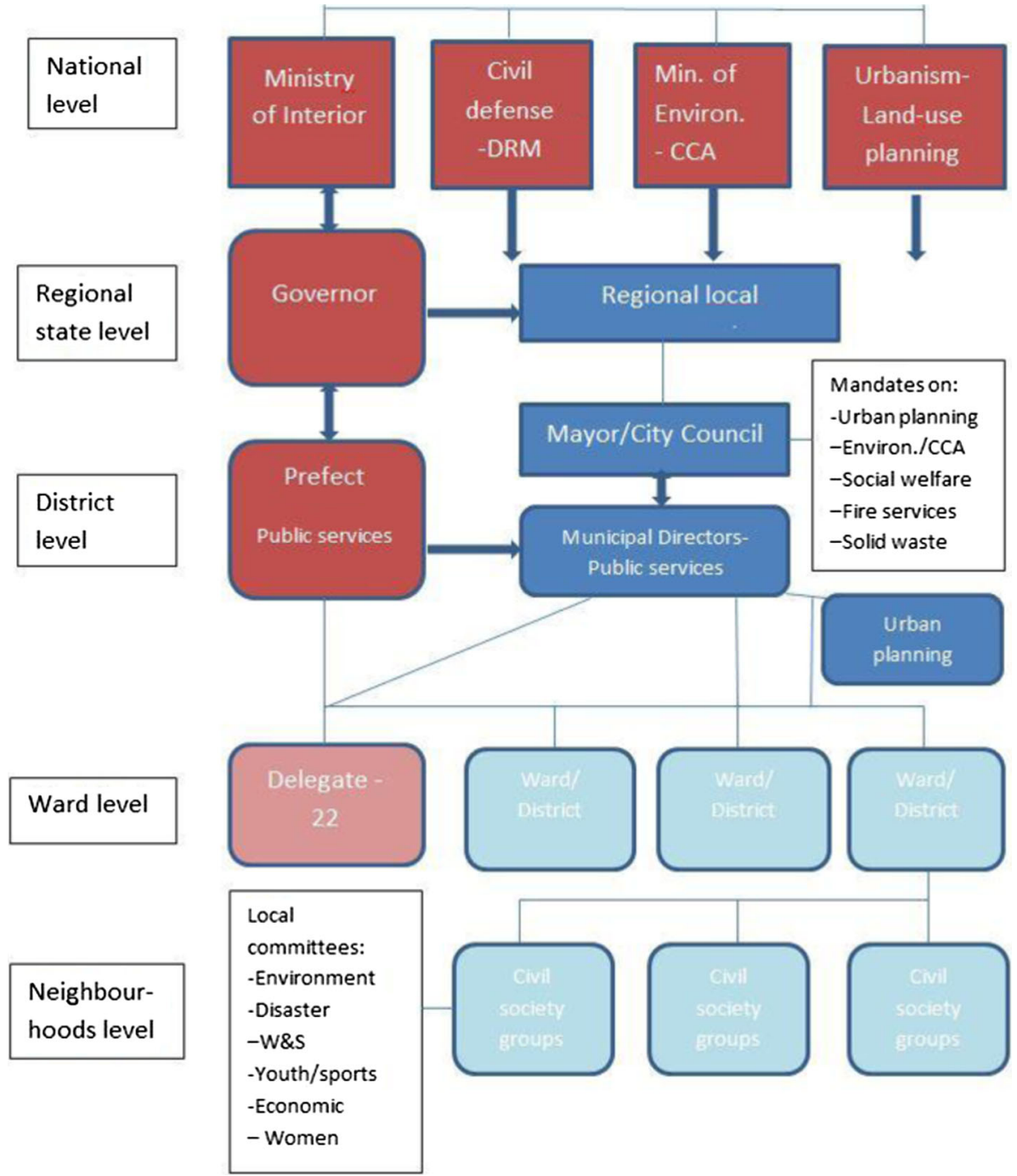

Fig. 2 Organizational structure of Saint Louis municipality and key state agencies engaged in urban development with 22 districts and 22 delegates (state appointed) 
functions for climate governance such as urban planning, adaptation/environment, disaster risk management, storm water management, and local administration. This reflects upon the institutional inheritance from the French administrative system, which is characterized by a strong and centralized state dominance over municipal government and limited local autonomy (at regional and city levels) (Pinto 2004).

Consequently, the regional state level (Governor) and the district state level (Prefect) represent the "strong" levels in terms of legal oversight and coordination and the provision of key relevant services related to urban land-use planning and control, water infrastructure, flood risk management, and resettlement of flood victims. The Prefect is on par with the Mayors in the authority hierarchy (see Figs. 2, 3). These regional and city-level state agencies played a key role in addressing underlying vulnerabilities for climate change with implications for adaptation and disaster risk management within the city territory. These deconcentrated state bodies are considered part and parcel of the decentralization reform, being located "next-door" to the municipal services. They to some degree overlap and integrate with the services of the municipality. The coordinating committees at the level of the Governor and Prefect tended to function through hierarchical instruments, for example, by providing information and guidance in environment and/or disaster risk management committees, while also instructing service agencies on what to do regarding general development (through development committees). There existed regional-level state

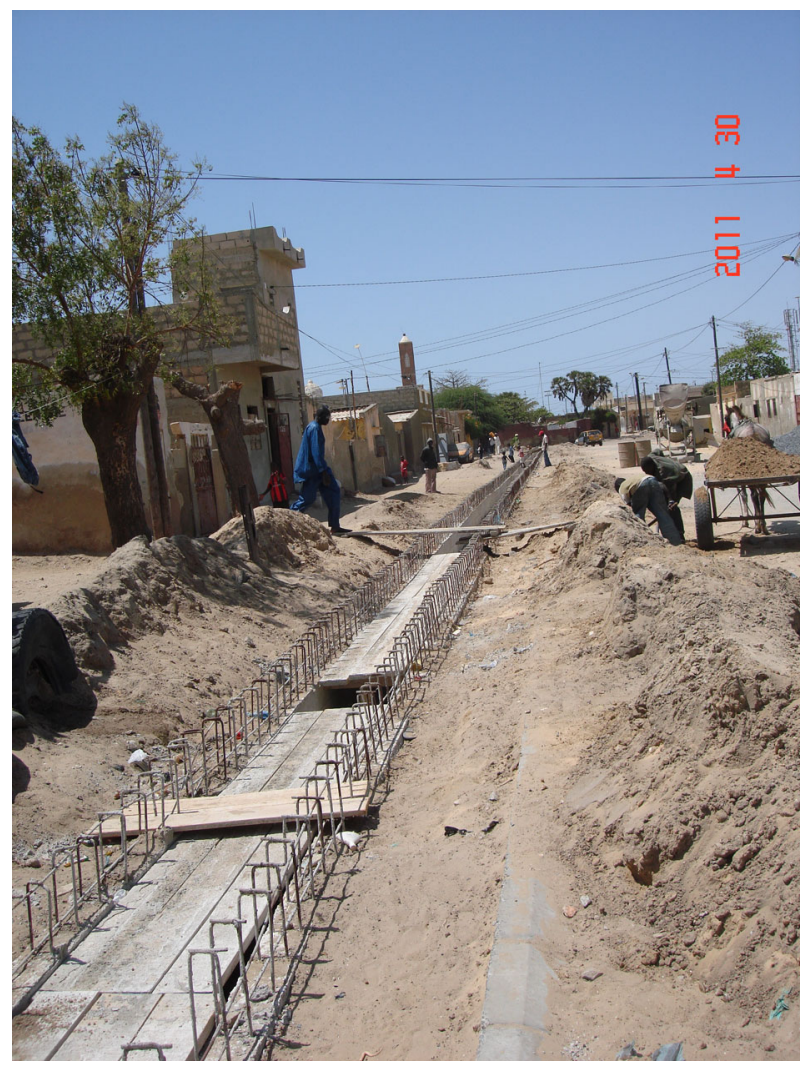

Fig. 3 Construction of new drains and sewerage in Diaminar (Picture: Trond Vedeld 2012) 


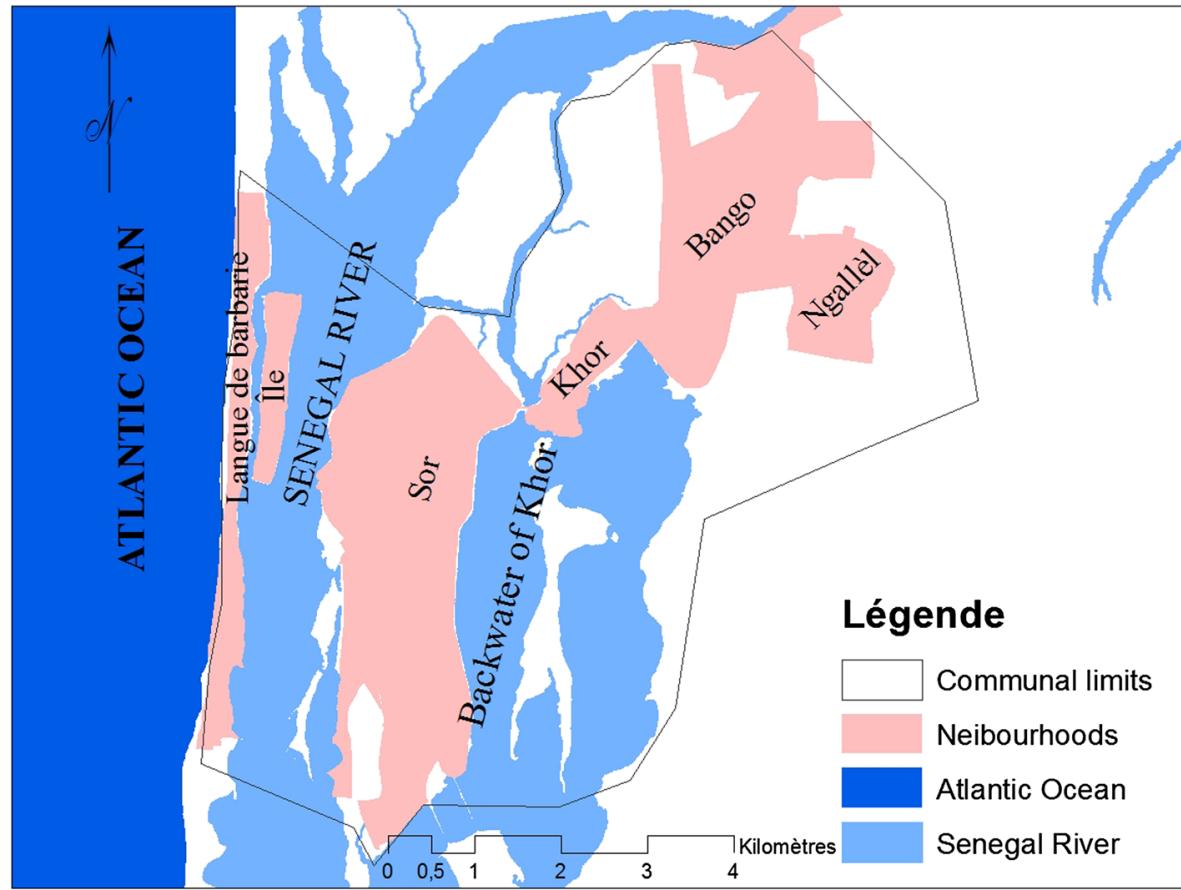

Fig. 4 Map of Saint Louis

coordinating committees for adaptation and disaster risk management, but these had limited administrative, technical and financial capacity to actually perform their duties within the city territory through operations on the ground. Also, important semistate and private corporations were involved in providing sewerage and water supply (international company). But these agencies were mandated to work mostly in formal areas and thus concentrated their work on middle-class neighborhoods and the city centers and the establishment of new housing areas in the peri-urban areas (e.g., northeast). The regional elected councils appeared weak in terms of administrative capacity and resources for coordinating services and development.

\section{Multi-level governance and barriers to municipal adaptive capacity}

There were critical multi-level governance constraints on the capacity of the municipality of Saint Louis for self-governing and provisioning of key services and infrastructure (Niang 2007; Coly et al. 2011b). The city of Saint Louis was managed by a City Council with 70 councillors and is administratively divided into 22 local districts managed by local District Councils. These councils were introduced in 1994 as an institutional reform to strengthen planning and implementation capacity at local level, and ensure greater participation of local people and civil society. The reform was inspired by the decentralization trends of the time, and the program was supported by several donor agencies (see below). To this end, Senegal was among the pioneers in Africa in introducing democratic central and local elections and a multi-party system evolved in the 1970s. 
Even so, remnants of the old centralization remained, and the mandate of the municipality was relatively limited to functions such as economic development planning, environmental management, strategic city planning and development, solid waste management, and development programming and prioritizing at the level of the District Councils. For example, the District Councils were not formally part of the decentralized structures. And in each of the 22 districts, there were local state appointed delegates who had remained with important roles in local development and oversight, and they kept reporting directly to the Prefect (these are the former "Chef de village"). Hence, the state was represented right down to the neighborhood level.

Moreover, the municipality was severely constrained financially at municipal and district levels. As suggested by the Prefect of Saint Louis, "the Mayor has no administrative, financial or technical services" (Interview May 10, 2012). The total annual budget is only about 3 million Euro per year, or about 15 Euro per capita per year, even if there existed a small budget line item (about $1 \%$ of the annual budget) allocated to flood risk management. However, these constraints did not hinder the combined state-municipality system to provide relatively good services and water infrastructure for flood risk management by African standards. Regional state agencies were in this regard actively engaged in urban development and urban investments, and interacted directly with municipal and local councillors and civil society actors (Fig. 3). This "compensated" to some extent for the lack of direct municipal investments. Direct state investments had resulted in Saint Louis having embarked upon several major investments in protective infrastructure against flooding in recent years, including a system of dykes and drains around the city and expansion of sewerage into some of the informal areas (e.g., in Diaminar, Island of Sor; Fig. 4).

\section{Centralized adaptation and disaster risk management}

Reflecting central state dominance in multi-level governance, the municipality of Saint Louis had no statutory mandate to govern in the areas of adaptation and disaster risk management, even if the role of the city in disaster risk management was recognized as important in the national disaster risk management strategy. The National Action Program on Climate Change Adaptation from 2006 involved limited guidance on urban adaptation. The agenda was centrally vested with the Ministry of Environment and Protection of Nature (at the time). However, the city planning office had recently hired a Climate Advisor, and this office enhances municipal governance on these issues (funded by a UN agency). Disaster risk management was also a central state domain and placed with the Civil Protection Agency of the Ministry of Interior. Emergency operations were headed by the Governor at regional level or the Prefect at departmental level (at the level of the municipality). A program to enhance coordination of public and civic actors in flood risk management with the Mayor was launched in the period 2006-2008 and supported by an NGO (Enda-Tiers Monde) and local state authorities (Water department and Senegal National Sanitation Office (ONAS) (Diagne 2007). However, these governance structures faded as the external support stopped. Few institutional traces of this initiative were found today, beyond the capability that might be left in the city planning and development office (ADC) (Vedeld et al. 2012, 2015b). There were only a few international NGOs that provided any substantive support for the flood risk/adaptation agenda, except Red Cross. Several UN agencies provided support to small capacity and training programs and a resettlement program for flood victims-involving an offer for families in Diaminar and 
Goxxumbacc to move to a peri-urban area (e.g., UNDP, UNEP, UN-HABITAT, UNESCO).

\section{Urban planning and water governance}

While the city municipality was firmly in control of strategic city planning through its planning office (ADC), land-use planning and enforcement of land zoning was largely in the hands of the regional state body of the national planning ministry. Except for the latest city strategic development plan, Horizon 2013 (cf. Horizon 2013), neither general city plans nor sector plans had directly addressed climate change issues, according to our review of these plans (Vedeld et al. 2012, 2015b). However, given that close to $70 \%$ of the population lived in formal and planned areas, the planning system was performing relatively well by African standards. Moreover, water and flood risk management had been substantially treated in the new strategic plan, reflecting both awareness and knowledge and organizational commitment to these issues on the part of the city planners and the leadership of ADC, as well as with the Mayor (Diagne 2007; Niang 2007; Ndour 2010; Jørgensen et al. 2012). In the interaction with the University of Gaston Berger, the city had carried out a set of studies on climate risks and vulnerability and related development issues (CLUVA 2014a, b). The city had over the years also carried out strategic plans in key relevant policy sectors, e.g., a sanitation master plan (2000-2010), and embarked upon various programs, e.g., a solid waste management programs and investment programs in sewerage and urban renovation in selected sites. But most of this work had actually been carried out by regional state bodies, not municipal agencies. Most if not all key agencies involved in water resources sectors, storm water, and flood risk management were directly organized under the state, as state bodies or semistate (sewerage) or private corporations (water supply) under state oversight. Even so, water governance in Saint Louis performed relatively well on several accounts, meaning processes of deconcentration of state bodies were supportive of many municipal-run development programs ref. performance of the sanitation agency-ONAS — and the National Water Utility (SONES) — a private French international corporation-providing water supply across the city, also in informal areas (see Table 1. Finally, a key issue was that the Mayor-and thus the city municipality-was not directly and formally involved in the governance structure for the management of the Senegal River, even if the river in so many ways directly affected the city.

Our interviews suggest that knowledge and awareness about the linkage between climate change, extreme rainfall, and flood risks were present at different levels among urban authorities, including City Council members, water resources engineers (ONAS), environmental officers (located with the Deputy Mayor) and urban planners (ADC), and the Governor, especially within the city planning office (ADC) (Interview May 8, 2012 Environmental officer). ADC is perceived as well positioned and capacitated to "take on a stronger role in coordinating climate risk responses" (Interview May 8, 2012 NGO representative).

However, covenants in the land-use act about illegal settlements in zones close to the river and the coast were mostly not strictly enforced due in part to political factors (e.g., political patronage). "A key problem is the interventions by politicians in critical land management decisions, which makes the state soft [on enforcing land management] ... Often the local state Delegate takes part in political conflicts and enhances local conflicts" (Interview May 8, 2012 City planners). This illustrated ambivalence in how the politico- 
administrative system governs land, administrators sought to move people out of flood risk areas, while politicians engaged to protect them in the same unsafe locations.

Hence, overall adaptation actions by the municipality were basically related to coping with flood risks and various incremental (no-regrets) adaptive activities, including emergency relief efforts with donor support. To much lesser degree did we find more significant transitional adaptation (see below).

\section{Integration of flood risk management in systems of coproduction}

The most interesting and unique aspect of Saint Louis' municipal administrative arrangement was the way a system of coproduction had been institutionalized within the municipal government and governance structure (Pinto 2004). This needs further explanation. Through the decentralization reform that started in 1994, the government established 22 District Councils (DCs) as administrative units (wards) alongside the state appointed delegates. The city also created a City Planning and Development Office (ADC) to serve as a political-administrative system in support of the DCs and their preparation of District Development Plans (DDP). This strengthened the administrative capacity and systems of local governance and coproduction at the local neighborhood levels. The reform received considerable donor support initially and made a real difference to the administrative capacity of the municipality. Level of donor support for this decentralization process had fallen over the last decade or so (Niang 2007). However, the municipal governance system was still relatively strong and functional regarding key planning functions.

We found that the ADC planners actively encouraged citizen participation in local development planning through continuous local dialogue and meetings (although within capacity limitations). The institutional system thus ensured local input into the DDPs and related development programs, which also had a bearing on flood risk management. The DCs rallied around the preparation of the DDPs and smaller development projects, including flood risk issues in DCs where these were perceived important. The unique feature of the DCs was that they were constituted from elected representatives of the most important local civil society associations within the local administrative territory (district). These were, e.g., local business groups, youth and sports groups, women's groups, fishermen's groups, or religious groups. We found 23 registered local associations in Diaminar and 94 in Goxxumbacc, reflecting a particularly strong presence of local associations and civic activity in both neighborhoods. This reflects upon the history of Saint Louis as an educational center and trading/fishing port. The District Councils were not part of the formal decentralized structure, but in practice worked in close relationship with city planners in local development. Hence, the DCs stood out as institutionalized coproduction arrangements that bridged the publicprivate divide (Ostrom 1996, 2005). The Youth and Sports Clubs, interestingly, were the most active in terms of facilitating the mobilization of people for actions in flood risk preparedness and management in flood-exposed communities (Ndour 2010; Vedeld et al. 2012). A problematic side of this municipal organization related to the issue of political accountability, since elections were not through secret ballots and the councillors did not report formally to the City Council and were not considered part of the formal devolved political structures. However, this dynamic structure had proved to have real strength in governance practice regarding the mobilization of local people through the local NGOs for planning, flood risk management, and development. The relative success of the Saint Louis local governance model had made it a countrywide approach to city and sub-city level governance in Senegal. 
Many genuine and broad needs and demands were discussed in these local encounters between ADC planners and local councillors and subsequently included in the DDPs (Diagne 2007; Ndour 2010; Coly et al. 2011a, c).

In Diaminar settlement, we observed such constructive interactions between urban planners (in ADC) and members of the District Council. Diaminar was typical of an informal settlement allowed to evolve on low-lying wasteland over the last few decades. Engagement by local Councillors had resulted in enhanced local flood risk awareness (through local training assisted by a local NGO) and the preparation of a local flood action plan and mapping of flood risk sites. The local District Development Plan (DDP) had been predominantly oriented toward finding solutions to flooding. Local state government bodies had recently responded to local demands and embarked upon a sewerage and urban restructuring program in parts of the settlement (with donor support). This had prompted the need for a resettlement program, with UN-HABITAT support and aided by ADC. The people of Diaminar, spearheaded by the Youth groups, would typically engage in cleaning of drains prior to the rainy season, placing sand bags or waste dumps to protect their own houses, and raise door steps of houses and latrines. Local people in 2010 were also observed providing cash as co-funding of fuel or repairs of local pumps operated by the fire brigade. This kind of civic engagement could be perceived as a reflection of a rich local culture and dense networks (Coly et al. 2011c).

Despite such local engagement and community capacity, however, the Diaminar community proved to be highly dependent on external assistance in order to reduce the impacts of the extreme flash flood event of 2010. They received assistance from the local fire brigade and from ONAS for pumping water, and from the local Red Cross for relocating people and providing emergency relief. Despite the national disaster risk management system providing support during this event, the coordinated response in terms of protecting people and assets and evacuating flood water were both late and inadequate.

In Goxxumbacc, we observed similar coordination and capacity problems. Goxxumbacc was an informal settlement on the outer spit fronting the Atlantic Ocean. The District Council of Goxxumbacc was established in 2000. It has historically faced severe coastal flooding and beach erosion issues of a magnitude that neither the local district nor the municipality could effectively handle due to the large potential investments required. The only realistic adaptive option had been perceived to relocate those houses along the seashore which were severely affected or at risk of being destroyed by coastal flooding and storm surges. Some families had been offered to resettle to another location in the city periphery, but few had opted to move (although accepting new housing plots in the resettlement scheme). The District Development Plan was focused on protection against beach erosion and infrastructural development (local roads, storm water). Despite many positive achievements by the local council and engagement of the local population in urban development planning, the settlement kept suffering from lack of sanitary infrastructure and sewerage. Annual flash floods due to inadequate drainage aggravated these issues. Pit latrines were common, solid waste was not systematically collected, and wastewater was handled mostly through autonomous systems (small "septic tanks") not through public sewerage. Local practices involved the pouring of wastewaters directly onto the streets, smaller streams/drains, or the sea.

Hence, none of the two districts studied were really capable of addressing local flooding and water resources management issues on their own, and both were reliant on external support for emergency relief as well as services and infrastructural investments for addressing underlying vulnerabilities. As observed by the Governor, "The district level is still very weak" and lacks financial resources (Interview May 8, 2012 with Governor's office). A key issue was observed to be that many of the projects proposed by local 
Table 2 Integration of adaptation and building of "resilient cities" in multi-level governance and coproduction

Location of responsibility/action on adaptation

Multi-level governance

Strategies/policies for adaptation and disaster risk management

Organizational homes for adaptation

Organizational homes for disaster risk management

Organizational home for flood risk management

Coordination mechanisms for adaptation and disaster risk management

Participation in governance/planning

Engagement of local groups in local action

Resources, budgets, and mandates for adaptation and flood risk management

Coproduction

Capacity for coproduction
Exists only at national level with limited policy guidance

Only at national or regional state level

At national, regional state levels, ward, civil society level

At regional state level

At regional state level (Governor) for both policy areas

Citizen groups engage in local development planning

Fairly strong

Medium at municipal level; small budget for flood risk management

Relatively strong and with some degree of institutionalization

residents through the DCs in the DDPs ended up not being funded, due to financial constraints at city and local levels (Vedeld et al. 2012, 2015a).

Moreover, local residents had also experienced how centralized political factors could overrule municipal government and lead to maladaptation. In 2003, the city was threatened by a major flood from Senegal River due to heavy upstream rainfall (cloudbursts). Reflecting in part the experience from the devastating 1999 flood that impacted the whole of Saint Louis, including Goxxumbacc, the Governor in consultation with the central government decided to have a 4-m-wide channel created across the spit (Land de barbarie) to open up a new outlet for Senegal River. This decision was taken without consulting the Mayor of the city or local citizens (except through a rapidly organized public meeting including people from Goxxumbacc). This channel has since 2003 reduced considerably the risk of river flooding in the city of Saint Louis (Kane 2010; Vedeld et al. 2012). But the channel has grown in breath from $4 \mathrm{~m}$ to $2 \mathrm{~km}$ in 10 years, and it has greatly increased other environmental issues severely such as coastal erosion and salinization of arable land and groundwater with impacts on local housing and settlements. Several local officials considered the channel an ecological catastrophe with uncertain long-term impacts.

\section{Discussion of findings}

\subsection{Adaptation actions at different levels}

Examining the roles of and relationships between diverse local state bodies, municipal agencies, and community-level actors suggested very diverse types of adaptation approaches and actions adopted. Tables 2 and 3 outline in more detail some deliberate actions taken by the government at state and/or municipal levels on adaptation per se (as a 
Table 3 Overview of the integration of adaptation, urban planning, and flood risk management

\begin{tabular}{|c|c|}
\hline & Adaptive actions taken \\
\hline \multicolumn{2}{|l|}{ Urban planning } \\
\hline $\begin{array}{l}\text { Strategic plan and integration of } \\
\text { adaptation }\end{array}$ & $\begin{array}{l}\text { Horizon (2013): Flood risk/water resources management } \\
\text { integrated. Limited mention of adaptation }\end{array}$ \\
\hline Land-use planning & $\begin{array}{l}\text { Done for } 70 \% \text { of city territory; flood risk zones known but to } \\
\text { limited degree respected and enforced }\end{array}$ \\
\hline Local development planning & $\begin{array}{l}\text { District Development Plans have flood risk management at their } \\
\text { core }\end{array}$ \\
\hline \multicolumn{2}{|l|}{ Disaster risk management (DRM) } \\
\hline $\begin{array}{l}\text { Early warning system and national- } \\
\text { local DRM system }\end{array}$ & $\begin{array}{l}\text { Reasonably well DRM capacity at national level; DRM } \\
\text { coordination committee with Governor; no home for DRM with } \\
\text { Mayor's office; only informal early warning system through } \\
\text { cell phones }\end{array}$ \\
\hline Resettlement of flood victims & $\begin{array}{l}\text { Small resettlement program (UN-HABITAT); large } \\
\text { implementation problems }\end{array}$ \\
\hline \multicolumn{2}{|l|}{ Flood risk/storm water management } \\
\hline $\begin{array}{l}\text { Organizational home for flood risk and } \\
\text { storm water management }\end{array}$ & $\begin{array}{l}\text { New ministry established for flood risk management (2012); } \\
\text { many state and private actors involved; no home with } \\
\text { municipality }\end{array}$ \\
\hline Sewerage & Sewerage mostly provided in formal areas \\
\hline Storm water infrastructure & Dykes, drainage, opened new outlet for Senegal River \\
\hline \multicolumn{2}{|l|}{ Adaptation } \\
\hline $\begin{array}{l}\text { Adaptation projects (incremental } \\
\text { approach) }\end{array}$ & $\begin{array}{l}\text { A few adaptation projects; substantive investments in flood risk } \\
\text { management }\end{array}$ \\
\hline
\end{tabular}

distinct policy area) as well as actions on the integration of adaptation in governance and selected service sectors (planning, water/storm water, disaster risk management). It is striking that adaptation — narrowly defined—remained a fairly nascent agenda with most of the key actors, and the agenda was not well integrated in planning and governance at the municipal level. Similarly, disaster risk management was also largely a national- and regional state-anchored agenda. Moreover, flood risk and storm water management were also not firmly anchored with any municipal agency. The notable exception was regarding the inclusion of flood issues in some DDPs and in the city strategic development plan (Horizon 2013).

\subsection{Levels of adaptation at different scales}

The subsequent section provides an overview of how various levels of adaptation were integrated at different scales into the multi-level governance system-with reference back to our definition of resilience and adaptation (cf. Table 4). The role of coproduction in multi-level governance is discussed separately.

\subsection{Multi-level governance and coproduction}

Regarding the multi-level governance context in Saint Louis, the state agencies and semistate/private corporations (e.g., in water supply, sewerage) contributed directly to 
Table 4 Levels of adaptation at different scales-observed examples

\begin{tabular}{|c|c|c|c|}
\hline Coping & Incremental adaptation & Transition & Transformation \\
\hline \multicolumn{4}{|l|}{ Individual level } \\
\hline $\begin{array}{l}\text { Constructed simple } \\
\text { dykes; higher } \\
\text { doorways; cleaned } \\
\text { local drains }\end{array}$ & $\begin{array}{l}\text { Built better houses and } \\
\text { protected assets } \\
\text { Participated in cleaning } \\
\text { drains before rains }\end{array}$ & $\begin{array}{l}\text { Avoided settlement in } \\
\text { flood risk zones } \\
\text { (mostly not respected) }\end{array}$ & None \\
\hline \multicolumn{4}{|l|}{$\begin{array}{l}\text { Collective level-civil } \\
\text { society }\end{array}$} \\
\hline $\begin{array}{l}\text { Relocated during } \\
\text { emergency flooding; } \\
\text { part-funded fuel for } \\
\text { pumping flood water }\end{array}$ & $\begin{array}{l}\text { Cleaned local drains; } \\
\text { coordinated early } \\
\text { response to floods; } \\
\text { early warning system; } \\
\text { organized waste } \\
\text { collection }\end{array}$ & $\begin{array}{l}\text { Enabled participation in } \\
\text { local planning/ } \\
\text { decision making } \\
\text { (women/youth) }\end{array}$ & $\begin{array}{l}\text { Institutional reforms may } \\
\text { have contributed to } \\
\text { some change in } \\
\text { attitudes and values } \\
\text { and awareness }\end{array}$ \\
\hline \multicolumn{4}{|l|}{ District level } \\
\hline $\begin{array}{l}\text { Coordinated adaptation } \\
\text { and disaster risk } \\
\text { reduction; facilitated } \\
\text { evacuation when } \\
\text { required during floods }\end{array}$ & $\begin{array}{l}\text { Undertook local flood } \\
\text { risk assessments; } \\
\text { trained groups; } \\
\text { developed local flood } \\
\text { risk plans }\end{array}$ & $\begin{array}{l}\text { Engaged civil } \\
\text { society/community } \\
\text { groups in flood risk } \\
\text { management and } \\
\text { planning }\end{array}$ & $\begin{array}{l}\text { Some change in attitudes/ } \\
\text { practice toward } \\
\text { government and } \\
\text { engagement of civil } \\
\text { society in local } \\
\text { governance }\end{array}$ \\
\hline \multicolumn{4}{|l|}{ Municipal level } \\
\hline $\begin{array}{l}\text { Assisted in flood } \\
\text { emergency } \\
\text { coordination; provided } \\
\text { relief support; ensured } \\
\text { health assistance; and } \\
\text { involvement of Red } \\
\text { Cross }\end{array}$ & $\begin{array}{l}\text { Carried out planning with } \\
\text { concern for flood risks; } \\
\text { risk and vulnerability } \\
\text { assessments; training; } \\
\text { and awareness raising; } \\
\text { hired climate advisor; } \\
\text { provided small funds } \\
\text { for flood risk } \\
\text { management }\end{array}$ & $\begin{array}{l}\text { Carried through } \\
\text { decentralization } \\
\text { reform (1995). } \\
\text { Changed structure and } \\
\text { practice of local } \\
\text { governance. Included } \\
\text { flood risk } \\
\text { management in } \\
\text { strategic plan }\end{array}$ & $\begin{array}{l}\text { Possible changes in } \\
\text { attitudes and awareness } \\
\text { and practice of ADC } \\
\text { planners about the need } \\
\text { for participatory } \\
\text { governance and } \\
\text { planning }\end{array}$ \\
\hline \multicolumn{4}{|l|}{ State level } \\
\hline $\begin{array}{l}\text { Provided emergency } \\
\text { assistance during } \\
\text { floods, e.g., fire } \\
\text { brigades/pumping of } \\
\text { flood water; organized } \\
\text { evacuation of people; } \\
\text { provided safety nets }\end{array}$ & $\begin{array}{l}\text { Prepared new climate } \\
\text { policies and } \\
\text { coordinating } \\
\text { institutions } \\
\text { Provided finance for } \\
\text { infrastructure (dykes, } \\
\text { storm drains, } \\
\text { sewerage). Weak } \\
\text { enforcement of land- } \\
\text { use principles in flood } \\
\text { zones }\end{array}$ & $\begin{array}{l}\text { Enabled } \\
\text { decentralization } \\
\text { reform (1994) } \\
\text { Funded dykes and storm } \\
\text { drains }\end{array}$ & $\begin{array}{l}\text { Some emerging } \\
\text { awareness among local } \\
\text { state planners of local } \\
\text { needs } \\
\text { Mal-transformation; } \\
\text { opened up in } 2003 \text { a } \\
\text { new outlet for Senegal } \\
\text { river }\end{array}$ \\
\hline
\end{tabular}

substantive urban planning and infrastructural development (drains, dykes) in protection of informal areas. In particular, the planners of ADC encouraged participation of citizen input to management of flood risks, water resources, and land-use planning. The decentralization reform from the mid-1990s represented an important transition in governance with transformative dimensions. It changed system structures, while probably also contributed to some changes in attitudes and awareness among planners and officials about local vulnerability and development issues and enhanced participatory dialogue. It seems that 
the small size/scale of the city and particular organizational structure facilitated relatively close day-to-day interactions between public officials and local people, and an institutionalization of coproduction in services. Processes of deconcentration of state services were coordinated with the decentralized and devolved municipal arrangements to ensure a fair amount of vertical integration by the municipality and urban state planners in collaborative development planning. In turn, this resulted in what may appear as above average standards in coverage and efficiency of service provision and infrastructure for addressing risks and vulnerabilities (compared to other African cities). Saint Louis performed relatively well in terms of investments in flood risk management, sewerage, and water supply (according to the indicators chosen, see Table 2). These observations may be a reflection of the distinctive history and local circumstance of Saint Louis (e.g., colonial and institutional history, dense civil society networks, many educational institutions, and economically diverse) and its location in Senegal; the country being an above average income per capita country by African standards.

Even so, the lack of financial and other resources within the municipality is a typical constraint across most cities in Africa-large and small (Wisner et al. 2015), and proved to be a critical barrier to its capacity to provide high-quality services and enable appropriate coordination in flood risk management. The city municipality operates under extreme financial constraints (annual municipal budget per is about 15 Euro for the city). ${ }^{2}$

\subsection{Community factors}

A key distinctive feature of Saint Louis relates to the high community capacity (or social capital) represented by the high density of local civic associations in the local settlements (evolved through the city's particular history). Dynamic civil society is recognized to be an important contributing factor to collaborative local governance in Africa in general (Crook 2010; De Sardan 2011; Crook and Booth 2011). We propose that this greatly enhanced neighborhood coordination in flood risk management and improve the relative efficiency of citizen participation in coproduction of adaptation. The dynamic association of community groups and local "Big men" in Saint Louis has also been provided a role within the local government system which facilitates their ability to voice claims and hold the municipal government accountable in urban planning and risk governance.

\subsection{Size, scale, and adaptive capacity of the municipality}

Despite being a fairly small city, Saint Louis has executed a set of smaller or incremental adaptation activities, some with transformative dimensions. It has also done reasonably well in coordination, provisioning, and enabling of flood risk management at the local level. This is in contrast to the capacity for adaptation revealed in the other four large African cities studied by CLUVA (Pauleit et al. 2015; Vedeld et al. 2015b). While the relative high potential of small towns in Africa for adaptation is recognized also by Wisner et al. (2015), this finding seemingly contradicts the findings of Rauken et al. (2014). They compared performance among municipalities in Norway and found the largest municipalities revealed the most advanced adaptation approaches. We propose that size and scale is not necessarily a decisive factor to ensure appropriate governance of adaptation. Rather, we suggest that if the scale of the city is a driving factor, it is so that small scale might

2 A municipality in Norway, for example, would have about 5000 Euro per capita at its disposal. This is an astonishing difference. 
enhance proximity in geographic and social terms between planners/authorities and citizens, and thus facilitate close relationships and accountability, and thus citizen participation, coproduction, and good governance.

\subsection{Prior experience with extreme floods}

Prior experience with extreme weather events and floods, and the fact that the city will be expecting more extreme events in the future, may have been contributing factors to the relative attention provided to flood risk management in Saint Louis. Locally, we found greater awareness and stronger response to floods among citizens and councillors of Diaminar compared to Goxxumbacc, which was the least severely impacted settlement by annual floods (Coly et al. 2012; CLUVA 2014b). However, prior experience with extreme events interfaces with other institutional and political factors, and it is hard to assign relative causal value to either. For example, in Saint Louis the lingering controversy around the opening of the new outlet of the Senegal River in 2003 has maintained flood risks and their potential impacts high on the local political agenda ever since (e.g., Interview May 8, 2012 Governor and City Planning Office). Hence, past experience may not necessarily be a major factor in explaining why climate risks over time have prompted attention by municipal planners and politicians.

\subsection{Political factors}

We argue that political factors were not decisive for many of the incremental adaptive approaches taken by municipal officials or local citizens to flood risk governance. This finding is supported by evidence from the case of Durban, South Africa (Roberts 2010; Roberts and O'Donoghue 2013). ${ }^{3}$ However, the personal engagement of the city Mayor in Saint Louis likely facilitated the engagement of planners and sector officials in addressing flood risks more profoundly, including the new city strategic plan. Moreover, political factors probably become decisive once important decisions are on the agenda about transitions in the governance or service delivery system, or about whether infrastructural investments should address vulnerability and inequality (Pelling 2011; Bulkeley 2013). For example, the decentralization reform in Saint Louis in 1994/1995 clearly required high level political backing. So did many of the high-cost investments in dykes, storm water infrastructure, and pumping systems. Political factors are also important for explaining why and how people are allowed to settle in unplanned and risky areas (Vedeld et al. 2015b).

\section{Contributions to theory}

This review of how adaptation has become established and operationalized at different scales in Saint Louis suggests that resilience was useful for pointing to important factors that define a resilient city and what and who need to become resilient. We suggest, however, that resilience was fruitful to the extent that the concept was defined to include

\footnotetext{
3 The Durban case illustrates the importance of local entrepreneurs among the city planners in experimenting with climate strategies and incremental adaptation. It suggests that political factors and limited funding can be overcome. It suggests that incremental adaptation and learning by doing lead to positive results provided there is cooperation across sectors (Roberts and O'Donoghue 2013).
} 
the scope for defined improvements of basic structures and functions of the system at risk (as conceptualized recently by UNISDR (2014) and IPCC (2012: 3, 2014). The concept should not be limited to notions of "bouncing back." However, reflecting the severe barriers observed in multi-level climate governance in the city, we needed analytical concepts that were more practical for our analysis than "resilience," and that provided a better understanding of how to act and move beyond resilience. To this end, the concept of coproduction in multi-level governance was fruitful for understanding drivers and barriers to municipal governance. The concept helped focus the analysis on the multitude of actors involved, interactional relationships, the high degree of centralization, policy and planning limitations, financial constraints, and the diverse levels of motivation and levels of responsiveness of public officials to local citizens. It also helped shift the attention from incremental adaptation actions (and resilience) to transitional adaptation and to transformation-in line with how Pelling (2011:69) and Bulkeley (2013) have proposed.

We propose several additional findings with relevance for theory. First, extreme financial constraints at municipal level did not constitute a decisive hindrance against adoption of incremental adaptation. The lack of political guidance from national level and lack of financial resources could be overcome by engaged municipal officials and local champions. Political factors were not decisive for getting incremental or small-scale adaptation activities going. Second, benign political factors and additional financial resources were required to promote more progressive transition in governance and larger (infrastructural) investments aimed at addressing risks and vulnerability and inequality on a broad scale. Third, weak political systems/decisions led to maladaptation, such as the opening of the new mouth of Senegal River and weak coordination in emergency flood risk management, such as with the major flood in 2012. Finally, despite deficiencies in climate governance, we found many interesting and substantive incremental adaptive actions ongoing at different scales-some which can be perceived as necessary experiments toward adjusting to climate change, and some that potentially carry the seeds of more fundamental policy or institutional reforms. Both incremental adaptation and more transformative actions seem to be required for building city resilience.

\section{Conclusions}

The paper suggests that strong coordination of climate change adaptation and disaster risk management should take place at city and sub-city levels, reflecting the "place-based" character of adaptation. However, adaptation cannot be addressed successfully at any single geographic scale or by any one category of actor. Effective collaboration across politico-administrative boundaries at multiple scales is required (see also Leck and Simon 2013). It should therefore be accepted that any particular context requires analysis of what multi-level governance structure might be appropriate for coordinated adaptation, risk reduction, and development efforts. Weak vertical and horizontal coordination and networking represented a critical barrier at all scales regarding flood risk management in Saint Louis. Moreover, the lack of financial and other resources from the urban state authorities for developing such collaborative networks for adaptation posed additional obstacles.

At the same time, the city level stands out as critical for coordination of adaptation at the local level and for urban development planning. While Saint Louis did not emerge as a climate "resilient" city, we found important adaptation experiments ongoing at both local and citywide levels with profound effect on flood risk management. In particular, the 
decentralization reform of the mid-1990s involved important institutional transitions. It might also have spurred transformational changes, included changes in values and attitudes of public officials and citizens. The institutional reform facilitated stronger dialogue between government staff and local citizens over time. We suggest that small size and simple organizational structure (few bureaucratic layers) combined with committed leadership and organizational cultures facilitated active citizen input into service delivery and coproduction in flood risk management. Active civic engagement and dense associational life likely prepared the ground for citizen action at the local level. Demands were placed on urban officials for support to flood risk reduction and drainage. Hence, we propose that the arrangement of coproduction within the system of multi-level governance and the way governance was practised were the factors that best explained the relatively successful local adaptation approaches. If city scale is an explanatory factor in the analysis, small scale was what helped furthering local adaptation capacity. In this regard, we concur with Ostrom $(1996,2005)$ in that good agency performance resulted not from the capacity or strength of public sector agencies per se, but rather from increasing their responsiveness to residents/customers and from cooperation across the public-private divide. ${ }^{4}$ These kinds of changes may not have fully affected the political system, however, and thus have not (yet) reached their full potentials.

These findings resonate with the findings of Wisner et al. (2015) in their review of adaptation challenges in a set of small African cities and towns, including in Western Africa. A typical medium- to small-scale city like Saint Louis reveals potentials to protect residents and assets from climate related hazards and to mobilize local stakeholders and civil society for joint action. To this end, there is indication that small-/medium-scale cities may serve as initiators of climate smart experiments and even transition and transformations in their regional locations. For example, the resilience of Saint Louis was greater along most dimensions compared to the larger cities reviewed by CLUVA (cf. Vedeld et al. 2015b; Pauleit et al. 2015). ${ }^{5}$

In particular, we point to the severe vertical coordination issues related to relationships between state and municipal agencies and links between politicians, administrators, and planners (e.g., regarding the sharing of responsibilities and roles). For municipalities to become further empowered and to take the adaptation agenda forward, greater institutionalization of the agenda is required of values, attitudes, knowledge, and action among politicians at all levels. Effective action is hampered by the variety of development challenges confronting urbanization. Tensions prevail between conflicting sector agendas and priorities, and firm political commitment is lacking to the climate adaptation agenda at local, regional, and national levels (an issue which is well known across many cities in Africa, cf. Leck and Simon 2013, Hordjik and Sara 2014; Inderberg et al. 2015). Political priorities are accorded to a variety of high-profile development programs. Within climate risk management priority is with relief and coping measures when flood emergencies arise, rather than with long-term flood risk reduction and adaptation. Some key politico-

\footnotetext{
4 That being said, even in Saint Louis the coordination of urban adaptation and flood risk management by hierarchical instruments was relatively weak and fragmented. This is also not surprising given that this has also been observed in many other African countries (Cartwright et al 2012; Roberts and O'Donoghue 2013; CLUVA 2014b) as well as in many European countries (OECD 2009; Bulkeley 2010; Hanssen et al 2013; Rauken et al. 2014).

5 The large cities of Durban and Cape Town in South African may possibly be two exceptions to this, suggesting that scale may not be a "strong" factor in explaining success in building urban resilience (Cartwright et al. 2012; Roberts and O’Donoghue 2013).
} 
institutional policy measures that may enhance flood risk management and provide pathways toward transformation in Saint Louis are

- Decentralize more powers and financial resources to city and sub-city levels;

- Enhance greater responsiveness to informality and inequality among public officials;

- Provide the district level with a formal mandate, resources, and powers for (community-led) land development control and flood risk management;

- Continue to enable yet greater commitment to participation of poor citizens in coproduction of relevant services and local planning; and

- Put in place organizational homes and structures for coordination of the joint disaster risk management and climate change agendas, including for storm water management, supported by city-level climate action plans that shifts emphasis from relief to longterm climate risk reduction.

The particularities of the empirical situation in Saint Louis may be specific to the institutional history and contingent politico-administrative circumstances in the city region and in Senegal, reflecting the rich institutional history of Saint Louis as an educational, religious, economic/fisheries/trading, and administrative town (Diagne 2007; Coly et al. 2011b). However, the generic issue arises that trade-offs need to be made between competing policy agendas, e.g., between high priority development (e.g., sanitation and water supply) and the lower-priority climate adaptation and flood risk reduction agendas. Consequently, tensions between different political priorities thus need to be sorted out-and understood-between individuals in key government positions of both the political and the administrative system at different scales and across sectors of urban government. Such political priorities concern in particular who and what is to become resilient and how they should be supported by the governance and services systems. This relates to the meeting of demands and needs of all citizens-including the poor who reside in the most risky and vulnerable areas.

In conclusion, we suggest that more research is required to inform the debate on the links between urban politics, multi-level governance, financial constraints, coproduction, and resilient urbanization.

Open Access This article is distributed under the terms of the Creative Commons Attribution 4.0 International License (http://creativecommons.org/licenses/by/4.0/), which permits unrestricted use, distribution, and reproduction in any medium, provided you give appropriate credit to the original author(s) and the source, provide a link to the Creative Commons license, and indicate if changes were made.

\section{References}

Adger N, Lorenzoni I, O’Brien K (2009) Adapting to climate change. Thresholds, values, governance. Cambridge University Press, New York

Bache I, Flinders M (2004) Multi-level governance. Oxford University Press, Oxford

Betsill M, Bulkeley H (2007) Looking back and thinking ahead: a decade of cities and climate change research. Local Env 12(5):447-456

Bicknell J, Dodman D, Satterthwaite D (eds) (2009) Adapting cities to climate change. Understanding and addressing the development challenges. Earthscan Climate, London

Birkmann J (2010) von Teichmann K (2010) Integrating disaster risk reduction and climate change adaptation: key challenges—scales, knowledge, and norms. Sustain Sci 5:171-184

Bulkeley H (2010) Cities and the governing of climate change. Annu Rev Env Resour 35:229-253

Bulkeley H (2013) Cities and climate change, critical introductions to urbanism and the city. Routledge, Oxon/New York 
Carmin J, Anguelovski I, Roberts D (2012) Urban climate adaptation in the Global South: Planning in an emerging policy domain. J Plan Educ Res 32(I):18-32

Cartwright A, Parnell S, Oelofse G, Ward S (eds) (2012) Climate change and the city scale. Impacts, mitigation and adaptation in Cape Town. Routledge/Earthscan, Oxon

CLUVA (2014a) Main page. http://www.cluva.eu/deliverables/CLUVA_D1.7.pdf/. Accessed 10 March 2014

CLUVA (2014b) Main page. Available at http://www.cluva.eu/. Accessed 10 March 2014

Coly A, D’Almeida A, Diakhaté MM, Lo M, Sy BA, Ndour NM, Gueye S, Sall F, Sy AA (2011a) Report on climate related hazard in the city of Saint-Louis. Internal CLUVA report (D5.2), University of Gaston Berger

Coly A, Ndour NM, Gueye S (2011b) Assessment of the institutional capacity of the city of Saint-Louis. Internal CLUVA report (D5.3), University of Gaston Berger

Coly A, Ndour NM, Gueye S (2011c) Social vulnerability assessment in the city of Saint-Louis. Internal CLUVA report (D5.3), University of Gaston Berger

Coly A, Sall F, Weets G (2012) Changements climatiques et vulnérabilité des villes africaines - Saint Louis du Sénégal. Rapport de Synthese, CLUVA (D5.8), UGB

Crook RC (2010) Rethinking civil service reform in Africa: 'islands of effectiveness' and organisational commitment'. Commonw Comp Polit 48:479-504

Crook C, Booth D (eds) (2011) Working with the grain? Rethinking African governance. IDS Bulletins 42(2):97-101

De Sardan J-PO (2011) The eight modes of local governance in West Africa. In: Crook RC, Booth D (eds) Working with the grain? Rethinking African governance. IDS Bull 42(2):32-42

Diagne K (2007) Governance and natural disasters: addressing flooding in Saint Louis, Senegal. Environ Urban 19(2):552-562

Douglas I, Alma K, Magenta M, McDonnell Y, McLean L, Campbell J (2009) Unjust waters. Climate change, flooding and the urban poor in Africa. In: Bicknell J, Dodman D, Satterthwaite D (2009) Adapting cities to climate change. Understanding and addressing the development challenges. Earthscan Climate, London, pp 201-223

Hanssen G, Mydske P, Dahle E (2013) Multilevel Coordination of climate change adaptation: by national hierarchical steering or by regional network governance. Local Environ 18(8):869-887

Herslund L, Mguni P, Lund DH, Souleymane G, Workneh A, Ouedraogo JB (2012) Exemplary policies, strategies and measures. CLUVA deliverable D3.6. Available: http://www.cluva.eu/deliverables/ CLUVA_D3.6.pdf. Accessed 10 March 2014

Hordjik M, Sara LM, Sutherland C (2014) Resilience, transition or transformation? A comparative analysis of changing water governance systems in four southern cities. Environ Urban 26:130

Horizon (2013) Horizon 2030, Nouvelle Métropole Africaine, City Planning Office (ADC), Saint Louis

ICLEI (2014) Main page. Available at http://www.iclei.org. Accessed 10 March 2014

Inderberg TH, Eriksen S, O’Brien K, Sygna L (2015) Climate change adaptation and development. Transforming paradigms and practices. Routledge, London, pp 117-139

IPCC (2012) Managing the risks of extreme events and disasters to advance climate change adaptation. A special report of working groups I and II of the Intergovernmental Panel on Climate Change (IPCC). [Field, CB, Barros V, Stocker TF, Qin D, Dokken DJ, Ebi KL, Mastrandrea MD, Mach KJ, Plattner G-K, Allen SK,Tignor M, Midgley PM (eds.)]. Cambridge University Press, Cambridge and New York

IPCC (2014) Climate change 2014. Impacts, adaptation, and vulnerability. Summary for policy makers, part A: global and sectoral aspects. Contribution of working group II to the 5th assessment report of the IPCC, WMO/UNEP 2014

Jørgensen G, Herslund L, Sarr C, Nakouye N, Sine A, Workneh A, Workalemahu L, Bekele E (2012) Base line scenarios for urban development of selected case study areas. CLUVA deliverable D3.5. http:// www.cluva.eu/deliverables/CLUVA_D3.5.pdf. Accessed 10 March 2014

Kane C (2010) Vulnérabilité du système socio-environnemental en domaine sahélien: l'exemple de l'estuaire du fleuve Sénégal. De la perception à la gestion des risques naturels. Thèse de doctorat de $3 \mathrm{e}$ cycle, Université de Strasbourg

Kern K, Alber G (2009) Governing climate change in cities: modes of urban climate governance in multilevel systems. In: OECD. Competitive cities and climate change, OECD conference proceedings, pp 171-196

Leck H, Simon D (2013) Fostering multiscalar collaboration and co-operation for effective governance of climate change adaptation. Urban Stud 50(6):1221-1238

Manor J (2011) Perspective on decentralisation, working paper no. 3, ICLD. Swedish International Centre for Local Democracy, Visby 
Ndour NM (2010) Intégration de la question de l'eau dans la gouvernance urbaine: analyse des systèmes de décision dans la Commune de Saint-Louis. Mémoire de Master 2, UGB, Géographie

Niang D (2007) Gouvernance locale, maitrise d'ouvrage communale et stratégies de développement local au Sénégal: l'expérience de la Ville de Saint-Louis. Thèse de doctorat de $3^{\text {ieme }}$ cycle

O'Brien K (2012) Global environmental change II: from adaptation to deliberate transformation. Prog Hum Geog 36(5):667-676

OECD (2009) Competitive cities and climate change. OECD conference proceedings, Milan, Italy 9-10 October 2008

Osborne S (2010) Introduction: the (new) public governance: a suitable case for treatment? In: Osborne S (ed) The new public governance. Emerging perspectives on the theory and practice of public governance. Routledge, Oxon

Ostrom E (1996) Crossing the great divide: coproduction, synergy, and development. World Dev 24(6):1073-1087

Ostrom E (2005) Understanding institutional diversity. Princeton University Press, Princeton and Oxford

Pauleit S, Coly A, Fohlmeister S, Gasparini P, Jørgensen G, Kabish S, Kombe W, Lindley S, Simonis I, Yeshitela K (eds) (2015) Urban vulnerability and climate change in Africa-a multidisciplinary approach. Springer, New York

Pelling M (2011) Adaptation to climate change: from resilience to transformation. Taylor \& Francis Books, London

Peters BG (2008) The two futures of governing. Decentering and recentering processes in governing. 114 Reihe Politikwissenschaft/Political Science Series. Institut für Höhere Studien, Wien

Pinto RF (2004) Service delivery in Francophone West Africa: The challenge of balancing deconcentration and decentralisation. Public Admin Develop 24:263-275

Rauken T, Mydske PK, Winsvold M (2014) Mainstreaming climate change adaptation at the local level. Local Env. doi:10.1080/13549831.2014.880412

Roberts D (2010) Prioritizing climate change adaptation and local level resilience in Durban, South Africa. Env Urb 22(2):397-413

Roberts D, O'Donoghue S (2013) Urban environmental challenges and climate change action in Durban, South Africa. Env Urb 25(2):299-319

Satterthwaite D (2011) Editorial. Why community action is needed for disaster risk reduction and climate change adaptation? Env Urb 23(2):339-350

Satterthwaite D, Dodman D (2013) Towards resilience and transformation for cities within a finite planet. Env Urb 25(2):291-298

Satterthwaite D, Huq S, Pelling M, Reid H, Lankao PR (2007) Adapting to climate change in urban areas. The possibilities in low-and middle-income countries. IIED: Human Settlements Discussion Paper Series

Simon D (2010) The challenges of global environmental change for urban Africa, Urban Forum 21:235-248. doi:10.1007/s12132-010-9093-6

Sorensen E, Torfing J (2009) Making governance networks effective and democratic through metagovernance. Public Admin 87:234-258

Sorensen E, Torfing J (2014) Enhancing social innovation by rethinking collaboration, leadership and public governance. Social frontiers. The next edge of social innovation research, Nesta, Glasgow

UN-HABITAT (2011) Global report on human settlements 2011. Cities and climate change. Nairobi: UNHABITAT

UN-HABITAT (2014) The State of African Cities 2014. Re-imagining sustainable transitions. Nairobi: UNHABITAT

UNISDR (2012) 2012 Making cities resilient report. UNISDR, Geneva

UNISDR (2014) Online Page: http://www.unisdr.org/campaign/resilientcities/ toolkit/essentials. Accessed 8 March 2014

Vedeld T (2003) Democratic decentralisation and poverty reduction: exploring the linkages. Forum for development studies no 2

Vedeld T, Hellevik S, Kombe W, Kweka-Msale C, Coly A, Ndour NM, Guéye S, Klausen JE, Saglie I-L (2012) Report on planning system and government structure in 2 case cities. CLUVA deliverable D3.1. http://www.cluva.eu/deliverables/CLUVA_D3.1.pdf. Accessed 10 Mar 2014

Vedeld T, Kombe W, Kweka-Msale C, Hellevik S (2015a) Multilevel governance and coproduction in urban flood-risk management: the case of Dar es Salaam. In: Inderberg TH, Eriksen S, O'Brien K, Sygna L (2015) Climate change adaptation and development. Transforming paradigms and practices. Routledge, London, pp 117-139

Vedeld et al (2015b) In Pauleit et al (2015) 
Weber EP, Khademian AM (2008) Wicked problems, knowledge challenges, and collaborative capacity building in network settings. Public Admin Rev March/April 2008

World Bank (2012) North African Coastal cities address natural disasters and climate change. The World Bank, Washington

Wisner B, Pelling M, Mascarenhas A, Holloway A, Ndong B, Fay P, Ribot J, Simon D (2015) Small cities and towns in Africa: Insights from adaptation challenges and potentials. In: Pauleit $S$ et al. (eds) Urban vulnerability and climate change in Africa. Springer, pp 153-196. doi:10.1007/978-3-319-03982-4_5

Ziervogel G, Parnell S (2012) South African coastal cities: governance responses to climate change adaptation. In: Cartwright A, Parnell S, Oelofse G, Ward S (eds) (2012) Climate change and the city scale. Impacts, mitigation and adaptation in Cape Town. Routledge/Earthscan, Oxon, pp 223-243

Ziervogel G, New M, Archer van Garderen E, Midgley G, Taylor A, Hamann R, Stuart-Hill S, Myers J, Warburton M (2014) Climate change impacts and adaptation in South Africa. WIREs Clim Change 5:605-620. doi:10.1002/wcc.295 